\title{
Self-provisioning, Sustainability and Environmental Consciousness in Brno Allotment Gardens ${ }^{1}$
}

\author{
Lucie Sovová
}

ABSTRACT This paper $^{2}$ seeks to contribute to the topic of alternative food production, which has attracted the attention of both scholars and practitioners in the last years, together with the increasingly stronger critique of the current food system. In the past, allotment gardens played an important role in cities' food self-sufficiency, however they are often omitted from the current food production debate. In the Czech Republic, as well as other Central and Eastern European (CEE) countries, food selfprovisioning is still widespread. Traditional practices, often burdened with rather negative connotations from the socialist era, are nowadays interacting with the efforts of the local food movement and urban gardening trends rediscovered in Western Europe. Based on research from allotment gardens at Kraví hora, Brno, this paper investigates the socio-economic and environmental facets of the selfprovisioning of fruits and vegetables within this specific context and its relation to alternative food networks, reflecting on Smith and Jehlička's notion of "quiet sustainability". The different uses of allotments are described, as are the functions and needs they fulfil. Using the method of consumer diaries, the presented research aims to quantify the amount of fruits and vegetables produced at Kraví hora. Furthermore, gardeners' motivations and their level of environmental consciousness are outlined. The respondents' declared relationship towards nature is contrasted with their respective attitudes and behaviour patterns towards the natural environment. The conclusion is that allotment gardens not only improve the urban environment and provide space for community building in cities, but they also offer significant potential for food provisioning, which can be supported within the framework of alternative food networks and urban sustainability.

KEYWORDS Allotment gardens, urban agriculture, alternative food networks, quiet sustainability, food self-provisioning

\section{Introduction}

Allotment gardens as well as other types of food self-provisioning have proved to be powerful coping strategies in times of crisis. One of the often cited examples is the case of Cuba, where the halt of oil supply after the fall of the Soviet Union forced inhabitants to develop

Sociálni studia. Department of Sociology FSS MU, 3/2015. S. 11-26. ISSN 1214-813X.

1 This paper was supported by the Czech Science Foundation, Grant No: GA14-33094S "Forms and norms of alternative economic practices in the Czech Republic".

2 The paper is based on the author's diploma thesis Allotment gardens as part of alternative food production? Full text of the thesis (in Czech) can be accessed at https://is.muni.cz/th/323982/fss_m/. 
self-reliant localized food production sites in both rural and urban areas (Altieri et al. 1999). Resource scarcity and the need for higher self-sufficiency were also the main drivers for the so called victory gardens - urban allotments which suplied food for the inhabitants of Great Britain and other countries during the Second World War (Girardet 2004). Urban agriculture has proven a successful feature of numerous development projects in the Global South (van Veenhuizen 2006). In the last decade, a revival of food self-provisioning is taking place in countries affected by the economic crisis in Europe (Bakošová 2012) as well as in the US (Dutko et al. 2012).

Urban food production in the Global South is most commonly presented as a tool for fostering food security (de Zeeuw and Dubbeling 2009), whereas in the North it can be linked to a broad scope of issues including sustainable development, community empowerment, social inclusion and the search for alternative forms of food production in general (Taylor and Lovell 2014). The possibility of growing one's own food fulfils the concept of food sovereignty as the right of peoples to define their own food and agriculture systems (Forum for Food Sovereignty 2007). On a higher level, it contributes to self-sufficiency on the local, regional or even national scale and it can therefore be considered as a strategic asset. Most of the current cities' food is imported and hence susceptible to supply disruptions, fluctuations in fuel prices and other risk factors (Simms 2008). This vulnerability of modern urban settlements, together with the diversity of scenarios in which urban agriculture proved helpful in the past, has led to a reevaluation of this practice, as numerous studies on urban food production potential show (e.g. Grewal and Grewal 2012 for Cleveland, Ohio; MacRae et al. 2010 for Toronto).

In the Czech Republic as well as other Central and Eastern European Countries (CEE), food self-provisioning experienced its peak in modern history during the era of state socialism. Whereas some authors explain this phenomenon by market shortages in the planned economy (Alber and Kohler 2008), others add limited hobby options, the impossibility of travel and a general lack of unpolitical activities as other, possibly even more important, factors that led both rural and urban dwellers to their gardens (Duffková 2002; Jehlička and Smith 2011). Even twenty-five years after the fall of communism, gardening is still embedded in the Czech mentality and popular across different social and income groups. According to Smith and Jehlička's (2013) research, $43 \%$ of Czech households produced some of their food in 2010, whereas similar figures range only around $10 \%$ for the population of Western European countries (Alber and Kohler 2008).

While the popularity of gardening in the socialist era most likely contributed to the persistenly high incidence of this practice, it also casts a shadow on its current reputation. In an attempt to distance themselves from the socialist regime, policy makers prefer to adopt West inspired measures for sustainable development, failing to recognize the potential of already existing practices which are often seen as outdated and obsolete (Jehlička and Smith 2011). Private gardens in rural areas embrace more and more recreational features that are characteristic of a rather urban life style (lawns, swimming pools etc.) (Klvač and Ulčák 2008), while urban allotment gardens are accused of hindering the development of modern cities (Gibas 2011). The trend is to abolish allotment sites rather than include them in sustainability policies at any level of governance. 
The "shyness" connected to food self-provisioning is, however, also characteristic of environmental activists (de Hoop and Jehlička 2012) and advocates of the preservation of allotment gardens. Scholars emphasize the ecological benefits of allotments as urban green areas (Buček 2007) or their social function, describing them as spaces of recreation for the elderly (Keyzlarová 2007; Gibas et al. 2013). The production potential is generally neglected or even dismissed as inefficient in comparison to the market offer (Keyzlarová 2012: 58; Valešová in Gibas et al. 2013: 108). While West inspired alternative food networks such as community supported agriculture, organic food or community gardens gain popularity amongst growing groups of environmentally conscious consumers and healthy lifestyle followers, the traditional and much more widespread allotment gardens are marginalized.

This gap between the prosperous history of allotment gardens and the recent rediscovery of urban agriculture on the one hand and the current, rather unfavourable perception of Czech allotments on the other was the main motivation for the presented research. By inquiring into existing but virtually unexplored food provisioning activities in the allotments, this paper seeks to introduce this traditional practice into the current discussions on sustainable food production and alternatives to the conventional agro-food system. It provides quantitative data on food production in three allotment sites located at Kraví hora, Brno, investigating how much fruits and vegetables are currently grown in selected plots and to what level the gardens contribute to their users' food self-sufficiency. Gardeners' motivations for food growing and their attitudes toward and habits of food procurement are examined in order to compare this practice to the concept of alternative food networks. Finally, the results are used to estimate the overall potential of Brno gardens for the city's food supply. The goal of this paper is to offer specific data which can, despite their limited reliability, provide an argument which has until now been missing in the debates about the future of allotment gardens.

\section{Urban agriculture as an alternative in food production}

The reassessment of traditional agriculture and food related practices is especially relevant as the unsustainability of our current food system becomes more and more apparent. Increased attention of both scholars and civic society focuses not only on the negative environmental impacts of conventional agriculture but also on the unscrupulous and non-transparent practices of global food trade which threaten the future of small farmers and local economies.

In the globalized free market, the connection of consumers to their food weakens as the traceability of the origin of food becomes obscured. High mobility of goods and shipping between subcontractors increases the ecological footprint of the final product and poses a threat to food safety. It was the numerous and highly publicized food scares (e.g. mad cow disease or the more recent horse meat scandal) which aggravated public concern with food and led to what Goodman and Goodman (2009) call "the quality turn".

The search for safer, more sustainable and transparent means of food procurement results in what scholars describe as alternative food networks (AFNs). While the image of a network depicts the relations between different actors engaged in the processes of food production, distribution and consumption, the attribute "alternative" aims to differentiate those from the conventional agro-food system. One of the typical characteristics of AFNs is 
the effort to reduce the distance between producers and consumers, both geographically and socially. The relationship between these actors is presumably closer and therefore more transparent. Compared to the conventional food system, the consumer has a more active role. $\mathrm{He}$ or she is interested in the product's qualities as well as the environmental, social and ethical aspects of the production process. These concerns and demand for specific qualities can also be reflected in different pricing of the goods (Renting et al. 2003; Goodman et al. 2012).

Alternative food networks are often linked to the urban context - not only the majority of economic activity takes place in cities (Girardet 2004: 7), but their inhabitants also pursue the ideal of responsible consumption more often than rural residents (Goodman et al. 2012). At the same time, cities are the most vulnerable part of the current food supply chain, since they are home to most of the world's population (United Nations Population Fund 2007) and typically depend almost entirely on external sources for their food supply. AFNs contribute to the reshaping of this traditional divided relationship between cities and the countryside (Renting et al. 2003; Goodman et al. 2012). From this perspective, urban agriculture, i.e. growing crops and breeding animals within urban areas, offers significant potential for the development of AFNs (as long as it complies with their other attributes mentioned above).

It is not only its location, but most importantly the connection to urban ecological and economic systems that defines urban agriculture (Mougeot 2010: 10). This includes the use of human and material resources of urban origin and supply mainly for urban consumers. Furthermore, urban agriculture is influenced by urban circumstances such as legislation, high land competition, specific market situation and so forth (van Veenhuizen 2006). Urban agricultural sites, including gardens, have a positive impact on a city's environment. They contribute to $\mathrm{CO}_{2}$ absorption, diminish the urban heat island effect, retain rainwater, and decrease noise and dust pollution. Ecological agriculture sites support biodiversity and create refuges for organisms in urban environments (Okvat and Zautra 2011).

Moreover, significant environmental benefits are linked to localized food production. Shortening the transportation distance of food products reduces $\mathrm{CO}_{2}$ emissions, air pollution and overall fossil fuel dependence. With less transportation, less energy is required for food cooling, processing and conservation, which - apart from further reducing energy and material inputs - facilitates consumers' access to fresh, non-processed foods (Norberg-Hodge et al. 2012: chap. 2). In food self-provisioning or short and less formal supply chains, the packaging is typically reduced, which translates into other material and energy savings during its production and disposal.

Other environmental benefits typical for allotment gardens and similar small-scale food production practices include economical water management (use of rain water for irrigation), high crop diversity, and the use of composted organic waste as fertilizer, all of which contribute to the closing of nutrient cycles. Furthermore, the small plots typical of Czech allotments are suitable for simple tools rather than heavy machinery.

Finally, multiple indirect environmental benefits of urban agriculture have also been outlined. Proximity to residential areas creates social control which can help in the monitoring of production methods. At the same time, Okvat and Zautra (2011) claim that urban agriculture rebuilds consumers' relationship to food production. If agriculture is closer to people's homes, they can more easily reflect on its environmental (and other) impact and therefore 
also on their consumption choices. Last but not least, Smith and Jehlička (2013) praise household food production for the widespread sharing and distribution of surplus harvest, which contributes to reducing food waste in a way no conventional supply chain can achieve.

The environmental and, more broadly, the sustainability potential of urban agriculture is generally accepted. There are, however, very few studies which examine its actual contribution to food production, and research is especially lacking in the context of the Global North (Taylor and Lovell 2014). Similar to the Czech debate (see above), production potential is often eclipsed by other arguments such as general environmental benefits, community building and other social aspects. With no intention to discharge these, this paper aims at filling this gap by providing a close look at the concrete amounts of vegetabes and fruits produced in the researched area.

\section{Research methods and context}

The research was carried out in three allotment sites at Kraví hora, Brno. Gardening has a long tradition on this hill. The first allotment colony, Kraví hora 1, opened in 1934. Allotments Kraví hora 2 and Malina were established after World War II. The allotments currently cover a total area of 14 ha divided into 575 plots. Local branches of the Czech Gardeners' Association (the umbrella organization for most of the country's allotments) rent the land from Brno municipality and lease individual plots to gardeners.

The focus of the research, as implied above, was on food production, trying to provide both quantitative data and qualitative framing. The core research method were consumer diaries: over the course of six months (from the beginning of May to the end of October 2014) respondents recorded all the fruits and vegetables they harvested in their gardens and also all the fruits and vegetables their households acquired otherwise (typically bought). A total of fifteen respondents participated; thirteen of them finished the data collection. The consumer diaries were designed to answer the main research question: How much fruit and vegetables do respondents harvest in their gardens during the season and to what extent does this amount cover the total consumption of fruit and vegetables in their households?

The group of respondents was selected using a snowball sampling in cooperation with the gatekeepers (allotment officials). While the sample is therefore not representative, it does capture the diversity of gardeners observed in Kraví hora allotments and described by the users themselves. The structure of the sample in terms of age, education and economic activity is summarized in Table 1. Most of the respondents (11 out of 13) were women, however both the gardens and the produce were usually used by whole families, hence the category of gender is not so relevant.

The respondents were selected from all three allotment sites located at Kraví hora hill in order to consider variations in garden size and shape, influences of slope, shade, aspect and other local factors.

Secondary research questions were designed to capture the qualitative context of food production in allotment gardens. They included a review of the ecological sustainability of gardening practices (operationalized especially by the use of industrial pesticides and fertilizers), the monitoring and assesment of other sources of fruits and vegetables (in terms of 
length and type of the supply chain), the use of the harvest with focus on the importance of informal economics (sharing, gifts), and gardeners' perceptions of allotment gardens, their functions and benefits. ${ }^{3}$ Finally, the findings from Kraví hora were extrapolated to Brno city level: the average yield in respondents' gardens was calculated based on the data from consumer diaries and the estimated area actually used for food production, leading to an educated guess about the amount of fruits and vegetables that could be produced in all the city gardens and therefore the potential for the city's food self-sufficiency.

Table 1: Representation of selected demographic criteria in the respondent group

\begin{tabular}{|l|l|l|l|l|c|}
\hline \multicolumn{2}{|c|}{ Age } & \multicolumn{2}{c|}{ Education } & \multicolumn{2}{c|}{ Economic activity } \\
\hline under 35 & 2 & elementary & 2 & working & 5 \\
\hline $36-45$ & 2 & qualified workers & 2 & unemployed & 2 \\
\hline $46-55$ & 2 & high school & 2 & maternity leave & 1 \\
\hline $56-65$ & 3 & university & 7 & retired & 5 \\
\hline above 65 & 4 & & & & \\
\hline
\end{tabular}

Apart from consumer diaries, the research was complemented by the use of other methods. Non-participant observation served to assess the area dedicated to food production and the intensity of garden management (gardens with little human intervention versus paved surfaces, non-native and demanding species etc.) in 108 plots selected randomly across the allotment sites. The observation also provided a general picture of the allotments' users and their activities.

Semi-structured interviews were conducted with the representatives of the three allotment sites and the thirteen gardeners who participated in the data collection. When interviewing allotment officials, the focus was on allotment colonies as a whole - the area, number and demographic characteristics of the users, prevalent ways of using the gardens, ownership, and organizational structure. In the interviews with gardeners, questions revolved around their motivation for gardening, their relationship to the allotment and the community, their activities in the garden and their gardening practices, especially the use of industrial pesticides and fertilizers. These interviews, carried out in the first two months of data collection, were supplemented with observation and informal conversations with the respondents throughout the research period.

\section{Food production in Kraví hora allotment gardens}

According to the data collected in consumer diaries during the 2014 season, thirteen respondents produced in total $1588 \mathrm{~kg}$ of fruits and vegetables. The differences among respondents were substantial - the least productive garden yielded only a little more than $4 \mathrm{~kg}$, while the

3 For a more thorough analysis of these aspects please see the original thesis. 
most successful gardener produced $411 \mathrm{~kg}$ of fruits and vegetables - this range is depicted in Table 2 . On average, a $200-250 \mathrm{~m}^{2}$ garden yielded $122 \mathrm{~kg}$ of produce.

Table 2: Fruits and vegetables harvested in respondents' gardens $(\mathrm{kg})$

\begin{tabular}{|l|l|l|l|l|l|l|l|l|l|l|l|l|}
\hline 4,0 & 19,3 & 24,6 & 42,8 & 55,3 & 56,0 & 95,5 & 108,4 & 140,8 & 175,2 & 202,9 & 252,0 & 411,2 \\
\hline
\end{tabular}

Gardens were a significant source of fruits and vegetables for respondents' households, as shown in Figure 1. On average, $46 \%$ of fruits and vegetables registered in the consumer diaries originated from the allotments. This number (varying from 4 to $77 \%$ in the respondent group) expresses the share of garden produce in the total of fruits and vegetables obtained by the households. The level of self-sufficiency can be more closely expressed by the comparison of the food grown to the food consumed in respondents' households. This percentage is lower because part of the harvest was used differently than for self-consumption - it varies from 4 to $64 \%$, with an average value of $31 \%$.

Figure 1: Sources of fruits and vegetables

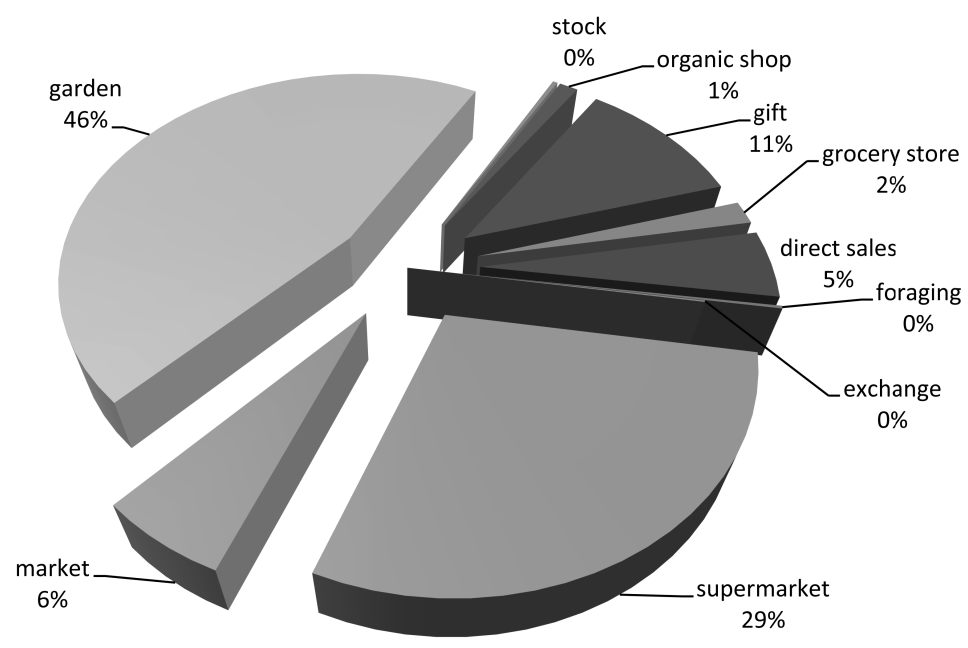

Most of the respondents live in shared households, therefore the food procurement and consumption involve two or even more people - the level of self-sufficiency would probably be higher if the gardeners were considered individually. Furthermore, self-sufficiency differs for each crop - most of the respondents found it necessary to buy some fruits and vegetables but had a surplus of others. These were conserved ( 9 respondents) or donated (11 respondents). The data about the use of the harvest revealed the great importance of informal economies $16 \%$ of the total amount of fruits and vegetables were given away as gifts, exchanged or shared, while none of the respondents sold their produce. 
Four of the respondents grew more food than their households consumed. This reveals that the level of self-sufficiency is determined not only by garden productivity - the "supply" side - but also by the "demand", that is, gardeners' eating habits. On average, SouthMoravian $^{4}$ households consume $85 \mathrm{~kg}$ of temperate zone vegetables and fruits per person and year (ČSÚ 2014a: Tab. 7d), whereas the respondents' households consumed $79 \mathrm{~kg}$ of (all) fruits and vegetables per person during the observed six months. It can thus be assumed that gardeners have higher than average consumption of fruits and vegetables, as Okvat and Zautra (2011) state. Most of the respondents (apart from exceptions described further) enjoyed a fairly diverse diet which included non-seasonal and exotic fruits and vegetables. It follows that food preferences influence the level of attainable self-sufficiency to the same, if not higher, extent as the size of the harvest.

The respondents dedicated on average half of their garden area to food production, compared to one quarter which was the average production area observed in the three allotment sites at Kraví hora. However, none of them aimed to achieve food self-sufficiency. Growing food did play a role in their motivations for gardening, but it was mainly connected to better taste and generally higher quality that they attributed to their harvest compared to fruits and vegetables available in the market: "We grow something and we grow it well. When you compare strawberries from the garden with the ones you buy, there is a huge difference. Anything that is grown in the garden is of much higher quality than when you buy it in the supermarket," respondent 13 said. Some gardeners in Kraví hora also specialize in varieties that are not common in the market, whereas others simply find joy and fulfilment in growing food: "I grow my own and I grow it the way I want it." (r. 10) "We have quite a lot in such a small area. It is this desire to grow food. And it is not greed, it just makes me happy to see it prosper." (r. 9) These attitudes correspond to the results of a survey among gardeners in Brno, where obtaining healthy food ranked as the third most appreciated benefit of gardening, after "ideal form of recreation" and "the possibility of spending time in nature without leaving the city" (Focus 2006). In Smith and Jehlička's research on household food production, fresh and healthy food was the main motivation for most respondents (2013: 155).

The research also confirms that gardening is perceived as a hobby and economic factors do not play a role in gardeners' motivations (Jehlička et al. 2012). Financial savings were rarely mentioned by the respondents and some of them even regarded gardening as uneconomical in strictly monetary terms. However, they were aware and appreciative of its other benefits: "We pay rent here. The garden does not pay off on what we grow here. But we take it that we can relax here, we have something to do. But otherwise it is not profitable." (r. 13)

\section{Kraví hora allotments as places of quiet sustainability?}

The data on food production in Kraví hora allotments imply that this practice possesses some of the characteristics of an alternative food network. The gardens undeniably shorten the distance from producer to consumer. They offer their users a more direct connection with the

4 The data refers to Cohesion region NUTS 2 which includes Southern Moravia and Vysočina regions. 
food they grow and eat, significantly contributing to their food sovereignty and self-sufficiency. It is also evident that the allotments fulfil other functions than mere food production and therefore embody a wider range of values than conventional food supply chains. What is more, the extent of gifting and sharing with family members and broader networks indicates that allotment gardens are, at least to a certain degree, escaping the market logic. This is a remarkable strength, especially considering the fact that many AFNs are, despite their transformative ambitions, dependent on the current economic system and operating within its infrastructure (Goodman et al. 2012).

Despite these commonalities, the position of allotment gardens in the realm of alternative food networks is rather specific. By definition, the actors involved in AFNs are consciously aiming to develop alternatives to the conventional food system. However, this motivation is missing in the case of Czech gardeners (Smith and Jehlička 2013). Environmental concerns, reflections on the current food system and the desire for change are rarely mentioned by allotment users in Brno (Přribylová 2005) and Prague (Gibas et al. 2013). The realized inquiry into gardeners' motivation confirmed these findings, as most of the respondents perceived gardening as a hobby without obvious ideological connotations.

In their research on household food production in the Czech Republic and Poland, Smith and Jehlička introduce the concept of quiet sustainability to describe "practices that result in beneficial environmental or social outcomes, that do not relate directly or indirectly to market transactions, and that are not represented by the practitioners as relating directly to environmental or sustainability goals." (2013: 155) According to the authors, gardening is an example of such practice. This claim is supported by the fact that their respondents emphasize fresh and healthy food as the main benefit of gardening. Although environmental impact is not a concern itself, the food is grown with minimal use of agrochemicals to achieve the desired qualities.

Smith and Jehlička suggest that home grown food is close to organic $-69 \%$ of the interviewed gardeners did not use industrial fertilizers, and $48 \%$ reported not using industrial pesticides (2013: 153). On the other hand, these figures also reveal a significant portion of gardeners who do use agrochemicals, especially pesticides. Přibylová's (2005) research on Brno allotment gardens reached similar conclusions with less optimistic framing of the ecological sustainability of gardening. Industrial pesticides were used on $44 \%$ of the gardens, and industrial fertilizers on $30 \%$ of them (ibid.: 60). According to the author, most of the respondents did not consider the environmental impact of their gardening practices. The gardeners were not informed about the possibilities of ecological garden management and they relied on old habits, convenience and personal preferences. The same situation was described in home gardens in the Moravian countryside (Hrazdírová 2010).

Smith and Jehlička (2013) themselves admit that basing their assessment of the ecological sustainability of gardening solely on respondents' statements can be imprecise. The actual amount of agrochemicals used could only be determined by soil sampling or other measurements. They concede that overuse of agrochemicals is more common in amateur gardening than in industrial agriculture. Hrazdírová (2010) explains this by a lack of knowledge about proper dilution and application of the preparations. 
Furthermore, Gibas et al. (2013) bring attention to certain inconsistencies between gardeners' reported attitudes and their behaviour: whereas most of their respondents criticized products of conventional agriculture as being artificial and full of chemicals, they did not refuse to use industrial pesticides or fertilizers in their own gardens. This contradiction was often explained by the necessity of applying agrochemicals in order to protect the harvest against diseases. In other cases, gardeners failed to recognize commonly used industrial pesticides and fertilizers as "chemicals", as recorded by Přibylová (2005: 59) and Matějovská (in Gibas et al. 2013: 84).

Similarly, Gibas et al. (2013) describe a conceptual division in the perception of nature. While most of the gardeners describe themselves as "nature-lovers", there is a clear line between controlled or non-intrusive nature, which is appreciated, and rather wild elements that threaten the harvest or the aesthetic appearance of the garden and therefore need to be fought against (Tvardková in Gibas et al. 2013: 74; Valešová ibid.: 104).

The respondents of the presented research confirmed the tendencies described above. The environment of the allotments was appreciated as natural, but weeds and pests were usually excluded from the desired nature. Eight respondents reported using industrial pesticides despite their negative statements about the "chemical" products of conventional agriculture and their general perception of their own produce as healthy and natural. The respondents were generally open to ecological alternatives of garden management, but still regarded the use of agrochemicals as a necessity. Diseases spread fast from one plot to another, making the use of pesticides indispensable, they claimed. Gardeners also complained about the low quality of the soil at Kraví hora, which requires fertilizing. In this case, however, they were more likely to use natural fertilizers such as manure or compost. Five respondents reported using industrial fertilizers. When choosing between artificial and natural remedies, efficiency and sanitariness were most important to consider, whereas environmental concerns were hardly mentioned.

Contrary to this prevalent practice, three respondents managed their gardens organically, using permaculture principles or ecological pest control. These gardeners showed higher levels of environmental awareness in the interviews and they also displayed more conscious shopping habits. Respondent 1 bought organic fruits and vegetables exclusively; the consumer diary of respondent 10 revealed almost no purchases in supermarkets and a strictly seasonal diet. Respondent 2 also aimed for local and seasonal consumption, linking her own gardening experience to the issues of the current food system:

When you learn how much work it takes to grow something and the stallholder is selling it for nothing... it is hard. And obviously he cannot compete with supermarkets, where it is even cheaper. And when you don't fertilize, it is small and people don't like it. But maybe now they might like it, nowadays many people know. I noticed that often people walk around the market stalls and ask what is Czech. People want Czech vegetables, they don't want imported garlic. It's become a topic.

Nevertheless, similar reflections were rather rare in the sample and according to the consumer diaries most fruits and vegetables were purchased in supermarkets (see Figure 1). This is not consistent with Okvat and Zautra's (2011) assumption that gardening experience can 
stimulate responsible consumption. On the other hand, respondents' conventional shopping habits further emphasize the importance of the allotments for food procurement - it can be argued that self-grown produce substitutes food that would otherwise be purchased in long supply chains. In this way, the gardens substantially reduce the ecological footprint of the food consumed in respondents' households, without competing with local farmers, short supply chains and other alternatives.

\section{Extrapolating from Kraví hora: Brno gardens for self-sufficiency}

Based on the respondents' estimate of the area dedicated to food production and their harvest as captured in their consumer diaries, the average yield of thirteen observed gardens was $1.18 \mathrm{~kg} / \mathrm{m}^{2}$. As with other figures, this value varied significantly among gardeners, ranging from $51 \mathrm{~g} / \mathrm{m}^{2}$ to $3.5 \mathrm{~kg} / \mathrm{m}^{2}$. This variation reflects different approaches to garden management as well as differences in the use of the plots: from high-yielding crops grown in greenhouses with the use of agrochemicals to wild plants collected in permaculture gardens; from experienced gardeners dedicating most of their time to growing food to young families who use their plot mainly for weekend recreation and who are only starting to experiment with food production. Basing the extrapolation on the average yield acknowledges this diversity. As mentioned before, the respondent sample was not representative, but according to observation it also covers the diversity of Kraví hora allotment users in terms of plot use and prevalent gardening practices.

The calculated average yield was contrasted with several studies of urban gardens, as shown in Figure 2. The amount of harvest per area can vary significantly, depending not only on local climate but also on the composition of crops, as the examples from New York City demonstrate. The gardeners in the study of Gittleman et al. (2012) chose different fruits and vegetables in two subsequent years, which together with other influences resulted in notably distinct yield values.

Most of the data depicted in the figure are measured per year, whereas in the presented research little of the harvest could have happened outside the observed period. Furthermore, only Pinkerton and Hopkins (2009) dealt with allotment gardens as such. The comparison is therefore inaccurate; however it proves that the value obtained in Kraví hora fits within the common range. At the same time, it is comparable to conventional agricultural production in the Czech Republic - in 2014 the average yield of vegetables was $2.4 \mathrm{~kg} / \mathrm{m}^{2}$. (ČSÚ 2015: Tab. 2)

The city of Brno has 1281.5 ha of garden area ${ }^{5}$ (Ageris 2006). Assuming that all garden owners were to dedicate one quarter of their plot to food production (as the users of Kraví hora allotments did on average) and they were to reach the same yield, they could produce approximately 15,121 tons of fruits and vegetables per year. If garden owners grew food on

Garden areas are defined as a "continuous compact area of gardens which are directly connected to one another (either with shared fences or mutually separated)" (Ageris 2006: 14). This definition complies with the arrangement of Brno allotment sites and it excludes individual home gardens. 
half of their plots (as the respondents of the presented research did on average), the yield would be over 30,000 tons of produce citywide.

Figure 2: Yield of selected urban gardens

annual yield $(\mathrm{kg} / \mathrm{m} 2)$

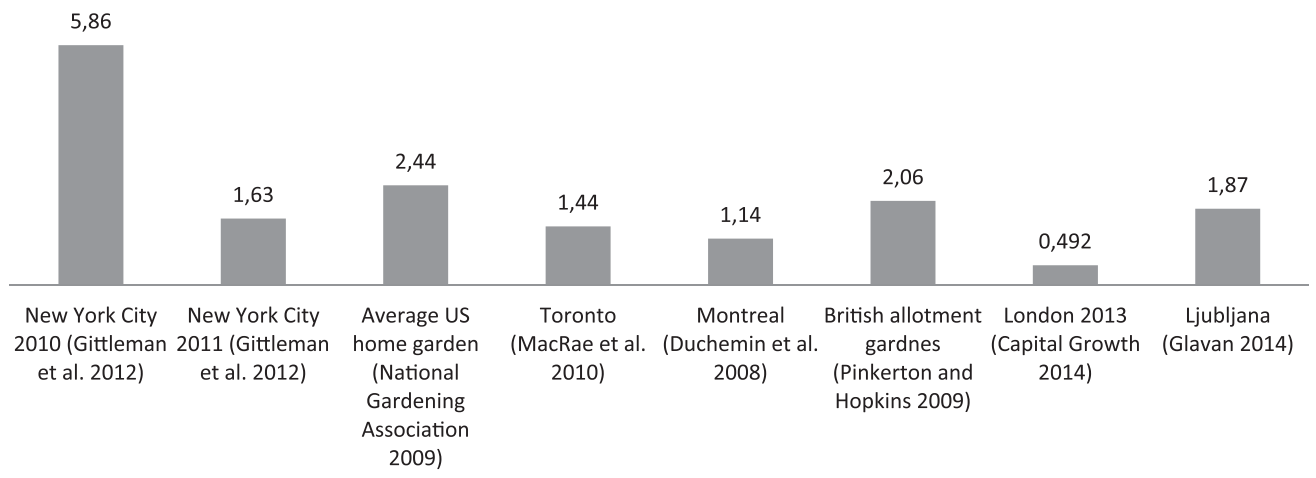

The comparison of this production potential with the amount of fruits and vegetables consumed in Brno leads to interesting results. In 2013, the average South-Moravian ${ }^{3}$ household consumed $41.14 \mathrm{~kg}$ of temperate zone fruits and $43.25 \mathrm{~kg}$ of vegetables per person (ČSÚ 2014a: Tab. 7d). The total of 377,508 Brno inhabitants (ČSÚ 2014b) therefore annually consumes 15,531 tons of temperate zone fruits and 16,327 tons of vegetables in their households. This implies that one quarter of Brno's garden area could provide for approximately half of the local household consumption of temperate zone vegetables and fruits. If half of the total garden area were to be used for food production, Brno households could be, at least hypothetically, self-sufficient in these foods.

\section{Conclusion}

Home grown fruits and vegetables are probably one of the most sustainable foods, especially when produced organically. Household food production reduces food transportation which uses substantial amounts of materials and energy and is a source of pollution. Furthermore, urban agriculture contributes to cities' resilience as it lowers their dependence on external supply. The data gathered in Kraví hora suggest that allotment gardens have a significant potential for food production. Without intentionally seeking self-sufficiency, the respondents were able to cover on average one third of their households' fruit and vegetable consumption from their gardens. Extrapolating from their average yields, the city of Brno could become self-sufficient in fruit and vegetable supply by using only half of the already existing garden areas.

The idea of complete self-sufficiency is, of course, rather exaggerated. Excessive focus on output maximization would probably diminish other benefits of urban gardening; not to mention the fact that Brno inhabitants are far from limiting their diet to local and seasonal 
products. Not even the advocates of urban gardening promote this way of food production as the only source of cities' food supply. Nevertheless, urban gardening can be a powerful asset in cases of supply outage - a scenario which might seem overly dramatic but it is not unrealistic. If urban food production is currently not a necessity, it should definitely be a right of city dwellers, fulfilling the principles of food sovereignty. Although based on a small sample and therefore limited in their reliability, the results of the presented extrapolation show that the production function of allotments is substantial and should no longer be omitted from the debates on urban sustainability strategies.

The presented research confirms previous findings captured by Smith and Jehlička's (2013) concept of quiet sustainability: Czech gardeners contribute (or at least have the potential to contribute) to sustainability without explicitly seeking to do so. The authors suggest that this lack of awareness is actually a strength, since the motivations of the actors involved are deeper than mere reaction to the problems of the food system in place, or the current local/organic food "fashion". However, the lack of environmental consciousness could also compromise the sustainability of this practice, for instance with the mentioned use of agrochemicals. In the described respondent group, the most successful gardeners (in terms of produce volume or the level of self-sufficiency) commonly used industrial pesticides and fertilizers and showed minimal concern with their environmental impact. The yields of the environmentally conscious gardeners were mostly lower, especially when their enthusiasm exceeded their skills or time available for gardening.

Finding the balance between the informed environmentalist and the experienced gardener seems to be the challenge Czech gardening should deal with in the future. Gardeners have already worked the land at Kraví hora for more than sixty years. From this perspective, their practices prove to be sustainable, even if not completely organic. Raising awareness on ecological agriculture and the broader context of food production can be one of the measures to support these buds of truly sustainable urban food systems. Connecting this traditional practice to the discourse of responsible consumption and alternative food networks could broaden the gardeners' horizons as well as improve the public image of allotments.

\section{References}

AGERIS. 2006. Vyhodnocení zahrádkářských lokalit na území města Brna. Brno: Ageris.

ALBER, Jens and Ulrich KOHLER. 2008. "Informal food production in the enlarged European Union." Social Indicators Research 89(1): 113-127.

ALTIERI, Miguel A., Nelso COMPANIONI, Kristina CAÑIZARES, Catherina MURPHY, Peter ROSSET, Martin BOURQUE and Clara I. NICHOLLS. 1999. "The greening of the 'barrios': urban agriculture for food security in Cuba." Agriculture and Human Values: 16(2): 131-140.

BAKOŠOVÁ, Barbora. 2012. "Mestskym pestovanim proti kríze.” Sedmá generace: XXI(5): 10-11.

BUČEK, Antonín. 2007. "Zahrady, sady a zahrádkářské kolonie v urbanizované krajině města Brna." Veronica: 21(19): 20-21.

CAPITAL GROWTH. 2014. Reaping Rewards: Can communities grow a million meals for London? Sustain. London. Retrieved November 17, 2014 (http://www.sustainweb.org/publications/?id=306). 
ČESKÝ STATISTICKÝ ÚŘAD. 2014a. Vydání a spotřeba domácností, statistiky rodinných účtů za rok 2013. Retrieved November 16, 2014 (http://www.czso.cz/csu/2014edicniplan.nsf/p/160018-14).

ČESKÝ STATISTICKÝ ÚŘAD. 2014b. Databáze demografických údajů za obce ČR. Retrieved November 16, 2014 (http://www.czso.cz/cz/obce_d/index.htm).

ČESKÝ STATISTICKÝ ÚŘAD. 2015. Definitivni údaje o sklizni zemědělských plodin 2014. Retrieved April 16, 2015 (https://www.czso.cz/documents/10180/20543367/2701411503.pdf/b5433efdb380-49dd-913f-e7de8801c903?version=1.0).

ČZS. 2014. Zpravodaj Českého zahrádkářského svazu 2.

DE HOOP, Evelien and Petr JEHLIČKA. 2012. "Reluctant Pioneers: Environmental NGOs and SelfProvisioning in Post-Socialist Czech Republic." Conference paper. Agriculture in an Urbanizing Society. Wageningen.

DE ZEEUW, Henk and Marielle DUBBELING. 2009. Cities, Food and Agriculture: Challenges and the Way Forward. Working paper no. 3. The RUAF Working Paper series. Leusden: RUAF Foundation.

DUCHEMIN, Eric, Fabien WEGMULLER and Anne-Marie LEGAULT. 2008. "Urban agriculture: multi-dimensional tools for social development in poor neighbourhoods." Field Actions Science Reports 1 .

DUFFKOVÁ, Jana. 2002. "První a druhý domov. Vývoj české záliby v chataření a chalupaření z pohledu sociologie." Přitomnost 2: 29-31.

DUTKO, Paula, Michele VER PLOEG and Tracey FARRIGAN. 2012. Characteristics and Influential Factors of Food Deserts. U.S. Department of Agriculture, Economic Research Service. Retrieved September 26, 2014 (http://www.ers.usda.gov/media/883903/err140.pdf).

FOCUS. 2006. Zahrádkářské kolonie města Brna optikou brněnské veřejnosti. ZO ČSOP Veronica, Brno. Retrieved February 10, 2014 (http://www.veronica.cz/dokumenty/Veronica_zahradky.pdf).

FORUM FOR FOOD SOVEREIGNTY. 2007. Declaration of the Forum for Food Sovereignty, Nyéléni 2007. Retrieved October 28, 2014 (http://nyeleni.org/spip.php?article290).

GIBAS, Petr. 2011. "Falešná zeleň a rajské zahrady.” A2 (19): 12-13.

GIBAS, Petr, Lucie MATĚJOVSKÁ, Arnošt NOVÁK, Eliška ROLFOVÁ, Veronika TVARDKOVÁ, Irena VALEŠOVÁ and Martin VESELÝ. 2013. Zahrádkové osady: Stíny minulosti, nebo záblesky budoucnosti? Praha: Univerzita Karlova

GIRARDET, Herbert. 2004. Cities People Planet: Liveable Cities for a Sustainable World. Chichester: Wiley-Academy.

GITTLEMAN, Mara, Keil JORDAN and Eric BRELSFORD. 2012. "Using Citizen Science to Quantify Community Garden Crop Yields." Cities and the Environment 5(1): Article 4.

GLAVAN, Matjaž. 2014. Economic Backgrounds of Food Production. Paper presented at Joint Training School on Urban Food Production, Ljubljana, Slovenia, 2014.

GOODMAN, David, Melanie E. DUPUIS and Michael K. GOODMAN. 2012. Alternative Food Networks: Knowledge, Practice and Politics. Abingdon: Routledge.

GOODMAN, David and Michael K., GOODMAN. 2009. “Alternative Food Networks.” Pp. 4:208-4:220 in International Encyclopedia of Human Geography, edited by Rob KITCHIN and Nigel THRIFT. Oxford: Elsevier.

GREWAL, Sharanbir S. and Parwinder S. GREWAL. 2012. "Can cities become self-reliant in food?" Cities 29(1): 1-11.

HRAZDÍROVÁ, Eva. 2010. Zahrádkář - producent čistých potravin či milovník chemie? Diploma thesis. Fakulta sociálních studií, Masarykova univerzita, Brno.

JEHLIČKA, Petr, Tomáš KOSTELECKÝ and Joe SMITH. 2012. "Food Self-Provisioning in Czechia: Beyond Coping Strategy of the Poor: A Response to Alber and Kohler's 'Informal Food Production in the Enlarged European Union' (2008)”. Social Indicators Research 111(1): 219-234. 
JEHLIČKA, Petr and Joe SMITH. 2011. "An unsustainable state: Contrasting food practices and state policies in the Czech Republic." Geoforum 42(3): 362-372.

KEYZLAROVÁ, Sandra. 2007. "Zahrádkářské kolonie - brněnský fenomén a územní plánování." Veronica 21(19): 22-23.

KEYZLAROVÁ, Sandra. 2012. Zahrádkaření a chataření - environmentální, sociální a ekonomické aspekty na př́kladu města Brna. Dissertation thesis. Př́rodovědecká fakulta, Masarykova univerzita, Brno.

KLVAČ, Pavel and Zbyněk ULČÁK. 2008. "Samozásobitelství potravinami - může být život na venkově luxusní?” Pp. 48-51 in Venkovská krajina 2008, edited by Jaromíra DRESLEROVÁ. Hostětín: Veronica.

MacRAE, Rod, Eric GALLANT, Sima PATELl, Marc MICHALAK, Martin BUNCH and Stephanie SCHAFFNER. 2010. "Could Toronto provide 10\% of its fresh vegetable requirements from within its own boundaries? Matching consumption requirements with growing spaces." Journal of Agriculture, Food Systems, and Community Development 1(2): 105-127.

MOUGEOT, Luc J. A. 2000. Urban Agriculture: Definition, Presence, Potentials and Risks, and Policy Challenges. Ottawa: International Development Research Centre.

NATIONAL GARDENING ASSOCIATION. 2009. The Impact of Home and Community Gardening In America. Retrieved October 28, 2014 (http://www.gardenresearch.com/files/2009-Impact-ofGardening-in-America-White-Paper.pdf).

NORBERG-HODGE, Helena, Todd MERRIFIELD and Steven GORELICK. 2002. Bringing the Food Economy Home: Local Alternatives to Global Agribusiness. London: Zed Books.

OKVAT, Heather A. and Alex J. ZAUTRA. 2011. "Community Gardening: A Parsimonious Path to Individual, Community, and Environmental Resilience.” American Journal of Community Psychology 47(3-4): 374-387.

PINKERTON, Tamzin and Rob HOPKINS. 2009. Local Food: How to Make it Happen in Your Community. London: Green Books.

PŘIBYLOVÁ, Petra. 2005. Vliv ekologizačnich tendencí v organizovaném městském zahrádkařeni. Diploma thesis. Fakulta sociálních studií, Masarykova univerzita, Brno.

RENTING, Henk, Terry K. MARSDEN and Jo BANKS. 2003. "Understanding alternative food networks: exploring the role of short food supply chains in rural development." Environment and Planning 35(3): 393-411.

SIMMS, Andrew. 2008. Nine Meals from Anarchy: Oil dependence, climate change and the transition to resilience. London: New Economics Foundation.

SMITH, Joe and Petr JEHLIČKA. 2013. "Quiet sustainability: Fertile lessons from Europe's productive gardeners.” Journal of Rural Studies 32: 148-157.

TAYLOR, John R. and Sarah TAYLOR LOVELL. 2014. "Urban home food gardens in the Global North: research traditions and future directions." Agriculture and Human Values 31(2): 285-305.

UNITED NATIONS POPULATION FUND. 2007. State of World Population 2007: Unleashing the Potential of Urban Growth. Retrieved March 10, 2014 (http://www.unfpa.org/sites/default/files/ pub-pdf/695_filename_sowp2007_eng.pdf).

VAN DEN BERG, Leo and René VAN VEENHUIZEN. 2005. "Multiple Functions of Urban Agriculture." Urban Agriculture Magazine 15: 1-3.

VAN VEENHUIZEN, René (ed.). 2006. Cities Farming for the Future - Urban Agriculture for Green and Productive Cities. Leusden: RUAF Foundation, IDRC and IIRR Publishing. 


\section{Author}

Lucie Sovová obtained her Master's degree at the Department of Environmental Studies, Faculty of Social Studies, Masaryk University in Brno. Apart from urban agriculture and alternative food networks, her research interests include alternative economies, ecological economics and degrowth. She is hoping to pursue these topics in her future work and studies in the same department.

Contact: es_lucie@centrum.cz 